\title{
Menerjemahkan Empati dan Penerimaan dalam Sesi Konseling
}

\author{
Monika Windriya Satyajati \\ Fakultas Psikologi Universitas Katolik Soegijapranata Semarang \\ emal:monika@unika.ac.id
}

\begin{abstract}
Giving empathy and acceptance for clients is such an important technique that needs to be done by every counselors. Despite of the counselors' psychological approach, empathy and acceptance are still mandatory skills that need to be mastered. While many references had cited the need to perform this skill, a detailed and practical example to do these skills is still rare to be found. This article reviews several references which show conversation between counselor and clients. One of the conversations chosen is a conversation by Carl Rogers in a Person-Centered counseling. The other conversation was done by Natalie Rogers in a Person-Centered Expressive Arts Therapy session. Following the conversations, explanation and analysis related the empathy and acceptance are given. The conversation samples given were categorized in four settings, which are (1) responding clients' question, (2) giving response for clients' blocking, (3) reflecting clients' emotional story, and (4) reflecting clients' emotional expression that was directed to counselor. The explanation showed that empathy and acceptance are difficult skills to be mastered. Nevertheless, those skills are still playing important roles in counselor sessions, especially when handling clients' emotional condition.
\end{abstract}

Keywords: Empathy, Acceptance, Counseling

\begin{abstract}
Abstrak
Memberikan empati dan penerimaan kepada klien adalah hal yang sangat perlu untuk dilakukan oleh setiap konselor. Terlepas dari pendekatan apa yang dipakai, empati dan penerimaan tetap menjadi keterampilan utama yang perlu dimiliki. Berbagai sumber ajar mengenai empati dan penerimaan telah menuliskan mengenai konsep ini, namun uraian secara lebih terperinci mengenai penerapannya belumlah diberikan. Tulisan ini mengulas mengenai beberapa kajian yang memaparkan percakapan antara konselor dengan klien pada sesi konseling. Percakapan yang diulas adalah percakapan antara Carl Rogers dengan kliennya dalam sesi konseling Person-Centered, dan juga percakapan antara Natalie Rogers dengan kliennya dalam sesi terapi seni dengan pendekatan Person-Centered. Uraian mengenai konsep empati dan penerimaan diberikan penulis terkait dengan setiap contoh percakapan pada berbagai kondisi konseling yaitu (1) menanggapi pertanyaan klien, (2) memberikan respons terhadap blocking klien, (3) merefleksikan muatan emosi terhadap cerita klien, dan (4) merefleksikan muatan emosi klien yang ditujukan ke konselor. Pemaparan tersebut menunjukkan bahwa empati dan penerimaan merupakan keterampilan yang sulit tetapi sangat diperlukan, terutama menghadapi berbagai kondisi emosional klien.
\end{abstract}

Kata kunci: Empati, Penerimaan, Konseling 


\section{PENDAHULUAN}

Menunjukkan

sikap

yang

mencerminkan empati dan penerimaan merupakan hal yang sangat perlu ditunjukkan oleh seorang konselor. Bukan hanya pada pendekatan humanistik saja, empati dan penerimaan merupakan keterampilan dasar yang perlu dimiliki oleh konselor, terlepas dari pendekatan apa yang digunakannya.

Sikap empati ditemukan dapat menimbulkan suasana konseling yang lebih fasilitatif, bahkan pada konselor yang masih belum berpengalaman sekalipun (DeStefano, Mann-Feder, \& Gazola, 2010). Beberapa pendekatan selain personcentered, juga seringkali menerapkan empati dalam praktiknya, misalnya pendekatan eksistensial (Frankel, Rachlin, \& Yip-Bannicq, 2012) dan pendekatan psikondinamika (Ursano, Sonnenberg, \& Lazar, 2004). Pada pendekatan eksistensial, konselor menggunakan empati untuk mengembangkan rapport. Terciptanya rapport yang disertai dengan munculnya empati membantu klien untuk dapat menjalani proses penanganan secara lebih optimal. Sedangkan pada pendekatan psikodinamika, proses mendengarkan klien secara empatik dilakukan agar konselor dapat benar-benar memahami permasalahan dan perasaan yang dialami oleh klien. Proses ini merupakan proses yang penting dalam membentuk transference, yang merupakan salah satu konsep penting dalam penanganan menggunakan pendekatan psikodinamika.

Beberapa penelitian mengungkapkan bahwa adanya penerimaan dalam sesi penanganan telah membantu memberikan luaran positif dalam penanganan pada klien dengan kasus depresi (Kim, 2010), gangguan panik (Satyajati \& Iswari, 2015), pemulihan dari adiksi (Satyajati, 2016), dan bahkan pada klien dengan agresivitas yang tergolong berat sekalipun (Singh \& Strandh, 2008). Penelitian-penelitian tersebut menguatkan bahwa adanya perasaan pada klien bahwa dirinya diterima, terlepas dari permasalahan apa pun yang pernah atau sedang ia hadapi, membantunya untuk lebih percaya pada konselor. Tentunya, dengan adanya rasa percaya ini, klien terbantu untuk dapat lebih nyaman dalam sesi konseling. Luaran positif lain pun akhirnya muncul setelah konselor menunjukkan adanya penerimaan.

Selain pada berbagai pendekatan, adanya empati dan penerimaan juga dibutuhkan pada berbagai teknik konseling. Carl Rogers memang lebih banyak menggunakan sesi percakapan secara lisan dalam melaksanakan proses penanganannya. Akan tetapi, dewasa ini, 
berkembang lebih banyak teknik konseling yang menggunakan media, terutama media seni. Salah satunya adalah yang dikembangkan oleh puteri dari Carl Rogers sendiri, yaitu Natalie Rogers. Terapi seni ekspresif dikembangkan oleh Natalie Rogers bagi para kliennya. Pada terapi ini, konsep utama yang digunakan adalah sama dengan intervensi person-centered, hanya medianya saja yang berbeda, yaitu menggunakan seni. Adanya empati dan penerimaan tentunya tetap menjadi konsep utama yang perlu diberikan pada klien untuk memfasilitasi mereka agar lebih terlibat dan ekspresif pada sesi terapi seni (Rogers, Tudor, Tudor, \& Keemar, 2012).

Pengetahuan mengenai diperlukannya empati dan penerimaan tentunya diketahui oleh kebanyakan konselor maupun para praktisi lain di bidang kesehatan mental. Namun, memberikan empati dan penerimaan adalah konsep yang terkesan klise di ranah psikologi. Kedua konsep ini adalah konsep yang relatif abstrak dan tidak secara rinci mempunyai petunjuk pelaksanaan. Ada kalanya konselor memahami adanya konsep ini, dalam praktiknya belum menunjukkan kedua konsep ini secara nyata. Empati dan penerimaan adalah keterampilan dasar yang seringkali dipelajari seiring bertambahnya jam terbang seorang konselor, namun masih sulit untuk diuraikan penerapannya secara teknis.

Pedoman secara praktikal mengenai pemberian empati dan penerimaan kepada klien, sejauh yang penulis ketahui, masihlah terbatas. Beberapa sumber memaparkan kutipan dari sesi konseling Carl Rogers dan Natalie Rogers bersama kliennya untuk memberikan gambaran yang lebih praktikal mengenai proses pemberian empati dan penerimaan (Lewis, Rogers, \& Shlien, 2008; Frankel, Rachlin, \& Yip-Bannicq, 2012; PsychotherapyNet, 2012). Tulisan ini akan menjabarkan kutipan-kutipan percakapan tersebut dan memaparkan landasan empati dan penerimaan yang didapatkan pada kutipan tersebut.

\section{TELAAH LITERATUR}

\section{Pondasi Dasar Pendekatan Person-}

\section{Centered}

Dalam mempraktikkan empati dan penerimaan, terlepas dari apa pun pendekatan yang dilakukan, Konselor tetap perlu memahami konsep dasar pendekatan Person-Centered. Kedua konsep dasar inilah yang menjadi landasan empati dan penerimaan pada konseling dengan berbagai pendekatan. Rogers (1980) menemukan kedua konsep dasar ini 
sebelum akhirnya merumuskan teori mengenai empati dan penerimaan.

Sebelum mempraktikkan empati dan penerimaan, setiap konselor perlu memahami kedua konsep dasar ini. Landasan keyakinan positif mengenai diri klien dimulai dari kedua konsep dasar ini. Bahkan pada klien dengan permasalahan paling parah sekalipun, jika Konselor sudah mempunyai landasan keyakinan positif terhadap klien, maka empati dan penerimaan pada klien dapat ditimbulkan dalam diri Konselor.

\section{Actualizing Tendency}

Pada dasarnya semua manusia (dan bahkan semua makhluk hidup) mempunyai kecenderungan untuk mengaktualisasikan diri. Kecenderungan ini juga berarti bahwa setiap manusia mempunyai caranya sendiri untuk mengarahkan dirinya menjadi potensi terbaiknya. Usaha untuk meraih aktualisasi ini dapat saja kacau atau terhalang, namun tidak akan hancur tanpa menghancurkan manusia tersebut. Seseorang yang melakukan perilaku yang dianggap buruk diasumsikan karena ia mencari contoh yang dapat ia gunakan dari lingkungan sekitar. Rogers (1980) menemukan konsep ini setelah melihat adanya temuan biologis, yaitu adanya pembelahan sel pada bulu babi. Ketika dilakukan perusakan, bulu babi tetap menunjukkan adanya pertumbuhan untuk menjadi satu organisme yang lengkap. Begitu juga pengamatan pribadi yang ia lihat pada kentang yang ditaruh di ruang bawah tanah rumahnhya. Meskipun tidak berhasil bertumbuh dengan sempurna, tanaman kentang tersebut tidak mati, tapi tetap terlihat bertumbuh. Hal ini membuat Rogers berpendapat bahwa pada kondisi kerusakan apa pun, semua organisme tetap berusaha untuk bertumbuh menjadi makhluk hidup yang lengkap dan menunjukkan potensi terbaiknya.

\section{Formalizing Tendency}

Konsep kedua adalah adanya kecenderungan bahwa individu selalu untuk berusaha menyatu dengan orang lain atau lingkungan lain untuk membangun suatu bentuk yang lebih sempurna. Hal ini berarti bahwa semua individu mempunyai kecenderungan untuk mencari individu lain dan bersamasama menjadi makhluk hidup yang lebih baik lagi. Rogers (1980) memaparkan gagasan ini dengan landasan berbagai fenomena di lingkungan sekitar. Misalnya saat melihat serpihan salju. Memang serpihan salju tampak sempurna, akan tetapi sebenarnya berasal dari bentukbentuk yang lebih kecil dan tidak 
sempurna. Rogers pun menyimpukan bahwa semua bentuk yang kita lihat, meskipun terlihat sempurna, merupakan kumpulan dari bentuk-bentuk lain yang lebih sederhana dan tidak sempurna. Oleh karena itu, ia menyimpulkan bahwa manusia pun, meskipun mempunyai kekurangan dan ketidaksempurnaan, akan cenderung membaur dengan lingkungan untuk menjadi kumpulan yang lebih sepurna. Hal ini dinamakan sintropi dan merupakan lawan dari deteriorasi.

\section{Konsep Empati dan Penerimaan}

\section{Empati}

Dalam mendefinisikan empati pada konseling, Rogers mengalami proses yang panjang. Pada awalnya, ia sempat mendefinisikan konsep empati, namun kemudian ia menambahkan konsep experiencing dari Gendlin dalam definisi empati yang ia buat (Rogers, 1980).

Dalam definisinya tersebut, Rogers (1980) menyatakan bahwa empati adalah suatu proses yang kompleks bagi konselor. Bersikap empati berarti mengesampingkan sudut pandang pribadi dan memasuki dunia klien tanpa adanya prasangka. Di sini, konselor sangat diharapkan untuk bersikap subjektif, atau bebas dari semua penilaian dan pandangan pribadinya. Hal ini tentunya tidak mudah dilakukan jika konselor tidak merasa aman dengan dirinya sendiri. Ketika empati dapat terbentuk dalam hubungan terapiutik, maka klien dapat dapat menunjukkan perkembangan dan memunculkan adanya self-exploration atau eksplorasi diri.

Saat kondisi empati muncul, Rogers (1980) menyatakan bahwa terdapat beberapa konsekuensi yang mengikuti. Konsekuensi yang pertama adalah bahwa empati menghilangkan alienasi. Klien yang merasakan empati dari Konselor akan merasa dipahami dan dapat menjalin hubungan positif dengan Konselor. Ia tidak lagi merasa Konselor sebagai orang asing baginya. Perasaan ataupun pengalaman yang sebelumnya ia sembunyikan karena dirasa abnormal, menjadi lebih dipahami. Klien pun tidak lagi merasakan perasaan atau pengalaman tersebut sebagai sesuatu yang aneh. Konsekuensi yang kedua adalah penerimaan. Ketika Konselor bersikap empati, klien merasa diterima sebagai dirinya yang sebenarnya. Meski tahap ini tampak sudah berada di luar tema empati, namun sebenarnya merupakan suatu poin penting dalam bahasan empati. Ketika empati menimbulkan penerimaan, klien menjadi lebih mampu menghargai dan peduli pada dirinya sendiri. Dampak terakhir dari empati berasal dari komponen yang disebut nonjudgmental quality. 
Rogers mempercayai bahwa penghakiman orang lain akan menghambat klien. Selain itu, penghakiman justru membuat klien ikut menghakimi diri sendiri dan menjadi kurang mampu menerima dirinya. Oleh karena itu kondisi empati tanpa penghakiman, dapat membantu klien meningkatkan penerimaan dirinya.

\section{Penerimaan}

Rogers (1980) mempunyai beberapa istilah untuk menggambarkan penerimaan atau acceptance, misalnya caring atau prizing. Dalam konseling dan psikoterapi pendekatan Person-Centered, istilah yang biasanya digunakan untuk menyebut penerimaan adalah Unconditional Positive Regard. Namun, dalam konteks di luar pendekatan Person-Centered, lebih sering digunakan istilah penerimaan. Hal ini menekankan bahwa penerimaan bukanlah sekedar menerima kondisi klien saja, tetapi juga tetap memberikan penghargaan pada klien, terlepas dari apa pun kondisinya. Konselor perlu selalu bersikap positif terhadap klien sebagai manusia secara utuh, meskipun tetap memberikan intervensi terhadap permasalahan yang mengganggu.

Ketika konselor dapat bersikap positif pada apa pun hal yang dilakukan oleh klien, maka pergerakan atau perubahan terapeutik dapat terjadi. Konselor memberikan penghargaan atas apa pun perasaan yang dimunculkan oleh klien tanpa memilih secara kondisional. Rogers (1980) menyebutkan bahwa salah satu cara ia dapat benar-benar memberikan caring pada orang lain adalah ketika ia tidak begitu takut dalam memberi atau menerima perasaan positif. Memberikan penghargaan tanpa berusaha untuk mengendalikan orang lain, adalah yang dikemukakan Rogers mengenai caring, atau unconditional positive regard. Kondisi penerimaan tak bersyarat di sini membantu klien untuk merasa nyaman dan percaya. Ketika ia merasakan hal ini, maka perilakunya pun juga dapat terpengaruh (Rogers, 1980). Individu yang dicintai secara apresiatif, bukan secara posesif, berkembang dan memperkuat dirinya yang unik.

Memberikan penerimaan tanpa syarat memang menjadi satu tahapan yang lebih rumit dibandingkan empati. Konselor perlu benar-benar bebas dari prasangka pada setiap perilaku atau pandangan klien yang seringkali dianggap buruk atau tidak tepat oleh orang lain. Dalam prosesnya, menurut pengalaman penulis, setiap menemui hal yang dirasa mengganjal dan menghalangi konselor untuk memberikan penerimaan tanpa syarat, maka Konselor perlu 
mengingat kembali kedua konsep dasar person-centered. Mengingat adanya actualizing tendency dan formalizing tendency membantu konselor untuk memahami bahwa perilaku klien yang mengganjal tersebut sebenarnya merupakan usaha klien untuk menjadi individu yang lebih baik. Namun memang klien belum mendapatkan adanya contoh yang tepat dari lingkungan mengenai perilaku yang sebaiknya ia lakukan. Memahami proses ini, konselor pun dapat memberikan empati dan kemudian berkembang pada penerimaan terhadap klien sebagai individu secara utuh meskipun ia masih menunjukkan perilaku yang dianggap buruk atau tidak sesuai dengan lingkungan.

\section{MENERJEMAHKAN EMPATI DAN PENERIMAAN DALAM SESI KONSELING}

Mengaplikasikan empati dan penerimaan bukanlah hal yang sederhana. Kedua konsep ini nampaknya terlalu abstrak sehingga seringkali salah dipahami oleh para konselor. Misalnya, konselor biasanya memahami adanya keterampilan untuk melakukan refleksi emosi dalam sesi konseling. Memang, jika dilihat dari contohnya, Rogers terkadang mengulang kata-kata klien. Hal ini membuat beberapa konselor beranggapan bahwa memberikan empati dilakukan dengan mengulang atau merepetisi apa yang dikatakan oleh klien. Padahal, Rogers tidak sekedar mengulang kata tetapi juga mengambil makna yang ia rasakan diungkapkan klien dalam katakata. Rogers mampu memahami apa saja yang tidak mampu diungkapkan klien secara langsung, dan terkadang diungkapkan kepada Konselor (Frankel, Rachlin, \& Yip-Bannicq, 2012).

Empati dan penerimaan tidaklah selalu berjalan bersama. Orang dapat saja berlaku empati tapi tetap menolak dalam waktu yang bersamaan (Rogers, 1980). Konselor bisa saja memahami sudut pandang klien dengan sangat baik. Namun, untuk tetap memberikan penghargaan positif pada klien bukanlah hal yang sederhana. Kondisi atau pandangan klien yang seringkali berbeda dengan konselor dapat membuat penerimaan lebih sulit untuk diterapkan. Oleh karena itu, kutipankutipan percakapan dalam sesi konseling dipaparkan pada tulisan berikut untuk memaknai lebih dalam mengenai konsep penerimaan dan empati yang lebih praktis tetapi tetap sesuai dengan konsepnya. Pemaparan mengenai contoh-contoh percakapan ini diuraikan pada berbagai kondisi konseling yaitu (1) menanggapi 
pertanyaan klien, (2) memberikan respons terhadap blocking klien, (3) merefleksikan muatan emosi terhadap cerita klien, dan (4) merefleksikan muatan emosi klien yang ditujukan ke konselor.

\section{Kutipan Percakapan Penerapan}

\section{Konseling dengan Empati dan}

\section{Penerimaan}

Dalam sesi konseling, seringkali ditemui klien yang terbiasa bertanya pada konselornya. Bertanya tentunya merupakan satu proses yang sangat baik terkait dengan proses berpikir kritis pada invididu sebagai sarana mendapatkan pengetahuan yang baru. Namun, hal ini tidak mutlak berlaku pada sesi konseling. Klien cenderung sering bertanya pada konselor karena berharap Konselor akan memberikan jawaban atas permasalahan yang ia hadapai. Namun, Rogers (1980) percaya bahwa sebenarnya tiap individu sudah mempunyai sumber daya yang cukup untuk dapat mengatasi permasalahannya sendiri. Keberadaan Konselor berfungsi sebagai fasilitator dan bukan sebagai pemberi nasehat atau solusi bagi klien. Oleh karena itu, konselor perlu untuk terampil dalam menanggapi pertanyaan klien, dengan mengutamakan konsep empati dan penerimaan. Dua contoh percakapan diberikan pada bagian ini yang merupakan kutipan dari konseling yang dilakukan oleh Carl Rogers (Lewis, Rogers, \& Shlien, 2008).

\section{Contoh 1.}

Klien : Bolehkah saya merokok sekarang?

Konselor : Tepat saat ini, merokok adalah hal yang benar-benar kamu inginkan.

Klien : (menghela napas, menangis, tertahan) Saya rasa saya sedih saat ini...

Percakapan antara Rogers dengan kliennya, diambil dari Lewis, Rogers, dan Shlien (2008)

Merokok adalah salah satu contoh perilaku yang akan disikapi berbeda-beda oleh berbagai orang. Sebagian orang merokok, sebagian orang lain tidak merokok tapi tidak keberatan dengan aktivitas merokok, namun sebagian lagi sangat tidak nyaman dengan aktivitas ini. Klien mungkin juga tidak memahami apa pandangan konselornya terhadap rokok. Namun, menjalani konseling adalah hal yang seringkali menimbulkan dampak emosional bagi klien. Oleh karena itu, klien yang merupakan perokok seringkali merasa bahwa dirinya perlu merokok. Biasanya hal ini dilatarbelakangi oleh kebutuhan klien untuk mendapatkan rasa tenang.

Terlepas dari apa pun pandangan konselor terhadap perilaku merokok, 
konselor perlu untuk mengesampingkan keinginan untuk menolak atau mendukung perilaku ini. Konselor perlu memahami bahwa ada kebutuhan besar yang ingin dipenuhi oleh klien saat ini, yaitu rasa tenang. Berbekal pemahaman empatik ini, konselor dapat memberikan penghargaan positif dan penerimaan pada kesadaran klien akan adanya kebutuhan terhadap rasa tenang. Setidaknya, klien sudah mengetahui bahwa kondisi emosionalnya tidak dapat dibendung lagi dan perlu untuk diregulasi. Pada contoh di atas, Konselor mengatakan “...benar-benar kamu inginkan" sebagai refleksi atas kebutuhan yang begitu besar yang ia tangkap dari klien. Kalimat ini juga bersifat sebagai pemantik, agar klien dapat mencari cara yang lebih tepat untuk dapat memenuhi kebutuhannya dalam meregulasi emosi. Cara yang lebih tepat, menurut Rogers (1980) adalah dengan mengungkapkan atau menyampaikan kondisi emosi tersebut secara langsung, bukan mengalihkannya dengan aktivitas lain, seperti merokok. Dan pada kutipan percakapan di atas, dapat dilihat bahwa Konselor berhasil memancing klien untuk mengungkapkan kondisi emosinya.

Kebiasaan untuk dapat mengungkapkan emosi klien mungkin tidak dapat langsung terbentuk dari satu kesempatan saja.
Contoh percakapan seperti ini perlu diulang setiap kali sehingga klien mulai terbiasa mengungkapkan emosinya. Klien yang terbiasa akan memahami dampak yang berbeda ketika ia mengungkapkan emosi secara langsung dibanding dengan mencari ketenangan dengan aktivitas lain seperti merokok. Hal ini diharapkan dapat membantunya membentuk coping yang lebih positif.

\section{Contoh 2.}

Konselor : (sebelum mengakhiri sesi) Baiklah, sampai bertemu lagi minggu depan.

Klien : Oke. Apakah mata saya terlihat merah dan sembab? (sehabis menangis)

Konselor : Kamu merasa matamu merah dan sembab?

Klien : Iya, sangat terasa.

Konselor : Oke. Sampai bertemu lagi minggu depan.

Percakapan antara Rogers dengan kliennya, diambil dari Lewis, Rogers, dan Shlien (2008)

Seringkali para konselor direktif merasa gemas karena konselor non-direktif seakan tak pernah menjawab pertanyaan. Sebenarnya, tidak ada larangan untuk menjawab pertanyaan. Akan tetapi, hal ini bukanlah hal yang diutamakan. Hal yang paling klien butuhkan pada dasarnya bukanlah informasi dari konselor melainkan adanya pemahaman dari perasaan yang ia alami. Pemahaman 
empatik ini merupakan landasan yang diperlukan dalam sesi konseling. Setelah itu, perlu diikuti adanya penghargaan positif pada klien. Penghargaan positif ini dapat berupa pengakuan dari konselor akan adanya pernyataan dari klien. Konselor ingin membantu klien tidak merasa terganggu dengan kondisi matanya namun hal ini tidak perlu ditunjukkan secara direktif. Adanya tanggapan terhadap pernyataan klien saja sudah cukup untuk memberikan penghargaan positif terhadap kondisi klien. Konselor juga tetap mempercayai bahwa klien dapat mengatasi kondisi ini secara mandiri dengan potensi yang ia punyai, sehingga tidak secara direktif menjawab 'ya' atau 'tidak'.

\section{Memberikan respon terhadap blocking}

\section{pada klien}

Dalam mengungkapkan permasalahan, adanya blocking atau sikap resisten pada klien adalah hal yang wajar terjadi. Terutama, ketika permasalahan yang ingin diungkap selama ini memang dihindari oleh klien atau mempunyai muatan yang menyakitkan bagi klien. Di sisi lain, mengungkapkan permasalahan yang mengganggu justru merupakan langkah awal bagi klien untuk dapat mendorong dirinya menemukan coping dari permasalahan tersebut. Oleh karena itu, blocking perlu disikapi secara cermat oleh konselor. Adanya empati dan penerimaan sangatlah dibutuhkan dalam menghadapi blocking klien. Contoh percakapan diberikan berikut ini sesuai dengan contoh dari Natalie Rogers pada sesi menggambar ekspresif (PsychotherapyNet, 2012).

\section{Contoh:}

Klien: (ketika akan memberikan komentar mengenai gambar yang baru ia buat) Sejujurnya, saya tidak tahu apa yang harus saya katakan....

Konselor : Tidak apa-apa jika kamu tidak ingin mengatakan apa pun terkait dengan gambarmu. Tetapi, saya menyarankan kamu mengambil waktu sejenak untuk menghargai karya yang sudah kamu buat. Setelah itu, kita bisa melihat apakah ada yang kamu rasakan atau ingin kamu diskusikan.

Dalam contoh di atas dapat dilihat bahwa Natalie Rogers memberikan empati pada apa yang dirasakan oleh klien. Rogers mampu memahami dan mengambil sudut pandang klien yang tidak dapat mengatakan sepatah kata pun. Ia juga memahami adanya konflik emosional di balik ungkapan klien yang merasa tidak dapat mengatakan apa-apa. Ia pun memberikan penerimaan pada kondisi tersebut. Ia memberikan penghargaan positif, dan secara terbuka, mengajak klien untuk ikut memberikan penghargaan 
positif pada hasil karyanya. Pada contoh ini, Natalie Rogers mampu memahami bahwa sebenarnya ada emosi yang dirasakan oleh klien, namun pada saat ini emosi tersebut masih belum diungkapkan atau yang tampak sebagai perilaku blocking. Ia dapat membantu klien menguraikan blocking ini tanpa menunjukkan penolakan atau penilaian negative terhadap perilaku ini.

\section{Merefleksikan muatan emosi dalam cerita klien}

Ketika klien sudah mampu merasa percaya dan aman dalam menjalani konseling, maka akan muncul berbagai ekspresi emosi yang ia utarakan. Kondisi yang sudah baik ini perlu diperkuat dengan adanya refleksi emosi yang melibatkan adanya empati dan penerimaan. Refleksi emosi bukanlah hal yang sederhana. Terkadang, konselor memilih untuk mengulang saja apa yang dikatakan oleh klien. Padahal, konsep yang sebenarnya dari refleksi emosi bukan sekedar mengulang tetapi juga memberikan empati yang lebih dalam terhadap emosi klien serta menerima emosi tersebut. Oleh karena itu, apa yang diucapkan oleh konselor saat memberikan refleksi emosi seharusnya mempunyai muatan emosi yang lebih mendalam untuk memancing klien melakukan eksplorasi emosinya lebih dalam pula. Hal ini dilakukan dengan adanya asumsi bahwa klien dengan permasalahan psikologis seringkali kurang mendapat kesempatan untuk mengekspresikan emosinya secara bebas. Contoh percakapan Carl Rogers dengan kliennya dipaparkan oleh Lewis, Rogers, dan Shlien (2008).

\section{Contoh 1:}

Klien : Entah sudah sejak kapan saya tidak lagi berbicara pada orangtua saya seperti kemarin ini... Saya benar-benar meledak dan saya katakan, 'Kalau memang kamu mau', ... Saya katakan, 'kamu dapat menyalahkan saya atas apa yang saya lakukan, tapi jangan salahkan saya atas apa yang adik saya lakukan. Dia cukup dewasa untuk bisa melakukan apa yang ia inginkan ...' Huff...

Saya benar-benar merasa dijatuhkan begitu dalam. Dan setelah itu saya menceritakan pada suami saya bahwa saya mencari hal dalam masa lalu saya yang bisa menyebabkan ini semua terjadi... yang membuat saya terpukul jatuh seperti ini. Karena untuk saja, pertengkaran saya dengan orangtua ini bukan saja hal yang sepele, tapi adalah hal yang sudah lama terjadi selama hidup saya antara saya, orangtua saya, dan adik saya... dan itu membuat saya merasa jatuh.

Konselor : Pertengkaran itu benarbenar menghantammu sangat dalam dan membuatmu mengingat semua hal yang sudah pernah kamu rasakan sebelumnya... Kamu benar-benar meledak. 
Dalam contoh ini terlihat bahwa klien sudah mau untuk mengungkapkan banyak hal yang ia rasakan kepada Konselor. Konten dari cerita klien merupakan tumpukan masalah yang sudah lama ia rasakan dan membuatnya ingin melampiaskannya namun tidak sekedar melampiaskan tetapi juga meledak. Dalam contoh ini, Rogers memahami emosi klien secara mendalam. Bahwa klien sudah sering merasa jatuh adalah hal yang sering ia rasakan. Rogers pun merangkaikan emosi tersebut pada kalimat awal refleksinya dengan menambahkan kata 'menghantam'. Pemilihan kata Rogers ini terkesan membesarkan muatan emosi tersebut. Ini dilakukan untuk meyakinkan dan memfasilitasi klien mengenai emosinya. Setelah itu, Rogers melanjutkan kalimat refleksinya dengan apa yang sedang dirasakan klien saat ini, yaitu 'benar-benar meledak', bukan hanya karena klien mengungkapkannya tapi karena klien juga sedang meledak-ledak dalam menceritakan permasalahannya ke Konselor.

\section{Contoh 1:}

Klien : Tapi sampai akhirnya orangtua menegur saya seperti itu, saya benarbenar terganggu. Tapi toh saya bisa mengabaikannya. Saya bilang pada orang tua saya 'jangan salahkan aku. Kamu hanya melakukan apa yang kamu inginkan saja!', dan kemudian pada adik saya... saya juga mengatakan hal yang sama. Tapi kemudian, selalu saja orangtua saya. Mereka menuduh bahwa saya yang melakukan hal buruk, dan adik saya jadi ikut-ikut. Dan adik saya yang membuat orangtua berpikir seperti itu. Selalu seperti itu.

Konselor : Itu yang selalu terjadi... selalu berakhir seperti itu, hmm?

Klien : Maksudku... kata-kata adikku, apa pun yang ia lakukan. Selalu saja membuatku teringat masa kecil. Saya tahu saya yang benar tapi kemudian orangtua selalu menyalahkan saya dan memuji adik saya sebagai yang terbaik.

Konselor: Dan inilah yang selalu kamu rasakan berulang kali sebelumnya.

$\begin{array}{rrrr}\text { Refleksi emosi } & \text { yang } & \text { Rogers } \\ \text { tunjukkan tidak selalu hanya }\end{array}$
mengulang, tapi juga dapat memancing klien untuk melanjutkan ceritanya. Rogers bukan hanya sudah memberikan empati dan penerimaan, tapi benar-benar menyatu dengan cerita yang disampaikan kliennya. Rogers menunjukkan adanya kemampuan untuk memandang cerita dari sudut pandang klien. Maka dari itu, Rogers dapat merasakan bahwa klien memandang masalahnya sebagai suatu hal yang selalu berulang dan mempunyai akhir yang selalu sama. Adanya empati dan refleksi yang menunjukkan penerimaan ini membuat 
klien merasa nyaman untuk menceritakan permasalahannya.

\section{Merefleksikan muatan emosi klien yang}

\section{ditujukan pada konselor}

Salah satu tantangan menjadi konselor adalah menghadapi klien yang menunjukkan muatan emosi yang diberikan pada konselor sendiri. Dalam sesi konseling, klien bisa saja tidak secara langsung mengungkapkan apa yang ia rasakan tentang dirinya. Klien juga mungkin saja menunjukkan berbagai ungkapan emosi ke konselor. Oleh karena itu, konselor perlu menjaga sikap empati, karena empati bukan sekedar memahami perasaan klien, melainkan benar-benar ada di dalam 'dunia klien' dan ikut mengalami apa yang ia rasakan tanpa adanya judgment. Konselor juga merupakan confident companion. Artinya, konselor perlu merasa menjadi teman yang juga mempunyai rasa percaya diri. Rasa percaya diri ini diperrlukan agar konselor benarbenar terlepas dari adanya judgment dari dalam dirinya mengenai apa yang dirasakan klien.

Contoh percakapan berikut diambil dari Frankel, Rachlin, dan Bannicq (2012), yang memaparkan sesi konseling yang dilakukan oleh Carl Rogers. Klien mengungkapkan ekspresi emosinya dengan banyak memberikan pernyataan emosional mengenai konselor. Selain empati, tentunya konselor juga tetap memberikan penerimaan meskipun klien datang dan mengatakan berbagai hal yang mungkin bagi orang lain akan menyulut amarah.

\section{Contoh 1:}

Klien: (memulai berbicara dengan nada yang kerasa tapi datar, tidak seperti nada bicaranya biasanya, dan tidak melakukan kontak mata ke Konselor ...) Kamu merasa saya ingin datang ke sesi konseling ini, tapi sebenarnya saya tidak ingin! Saya tidak mau datang lagi. Konseling ini tidak terasa baik. Saya tidak suka kamu. Saya benci kamu! Kamu seharusnya tidak pernah dilahirkan.

Konselor : Kamu sangat sangat membenci saya.

Klien: Kamu merasa bahwa ayah saya melakukan hal yang buruk pada saya, padahal tidak! Kamu pikir ia bukan lelaki baik, padahal dia baik! Kamu pikir saya mengharapkan hubungan intim, padahal tidak!

Konselor : Kamu merasa saya benarbenar salah merepresentasikan semua hal yang kamu pikirkan.

Klien: ...Kamu pikir kamu dapat membuat orang lain datang dan menceritakan semua hal padamu, dan orang lain merasa akan terbantu, padahal tidak. Kamu hanya suka melihat mereka makin menderita. Kamu merasa bisa menghipnotis mereka, tapi kamu tidak bisa! Kamu berpikir kamu baik, padahal tidak. Saya benci kamu. Saya membencimu. Konselor : Kamu merasa saya sangat senang membuat mereka menderita tapi tidak membantu mereka. 
Klien: Kamu merasa saya tidak pernah berada di jalan yang benar, padahal sudah. Saya membencimu. Semua yang saya punya hanyalah sakit, sakit, dan sakit. Kamu merasa saya tidak bisa mengarahkan hidup saya, padahal saya bisa. Kamu merasa saya tidak bisa menjadi lebih baik, padahal saya bisa. Kamu merasa saya punya halusinasi, padahal tidak. Saya benci kamu. (Terhenti lama, bersandar tapi tampak tegang, gesture kelelahan). Kamu merasa saya gila, padahal tidak. Konselor : Kamu sangat yakin bahwa saya berpikir kamu gila.

Klien: (Terhenti) Saya lelah, dan saya tak bisa bebas! (Nada suara tak berdaya dan menangis. Terhenti sejenak) Saya baru saja merasakan halusinasi dan saya harus mengusirnya! ...(Kemudian melanjutkan bercerita mengenai halusinasinya dengan nada suara yang sudah lebih tenang)

Menurut Frankel, Rachlin, dan Bannicq (2012), dalam sesi konseling ini Rogers benar-benar mampu berempati terhadap klien dan merefleksikan apa yang klien rasakan. Klien tidak memprotes dengan mengatakan pada Rogers, "Tapi kan Anda hanya mengulang-ulang perkataan saya," karena Rogers memang tidak sekedar mengulang-ulang perkataan. Rogers mengambil makna emosi dari setiap perkataan klien.

Hal yang menarik dan cukup berat dalam konseling ini adalah bagaimana Konselor dapat bersikap tenang dan menjadi confident companion. Konselor mendahulukan apa yang dirasakan klien. Meskipun manusia baisanya memberikan reaksi marah, takut, atau sedih ketika dihadapkan pada orang yang secara langsung mengungkapkan emosi negatif padanya, namun Konselor perlu mengutamakan perasaan klien terlebih dahulu sehingga menyadari bahwa emosi negatif tersebut tidak tidak sepenuhnya ditujukan pada Konselor. Hal ini membutuhkan empati dan penerimaan yang sangat besar dari Konselor. Konselor perlu mengesampingkan kemungkinan merasa tersinggung atau marah karena kata-kata klien yang emosional dan terus merefleksikan apa yang klien katakana sesuai dengan ekspresi yang ia tangkap.

Pada contoh 1, klien yang marah ke Konselor akhirnya justru dapat tenang dan menceritakan permasalahan yang ia rasakan sebenarnya. Hal ini terjadi karena Rogers memfasilitasi amarah yang ingin diungkapkan klien. Setelah semua amarah tertampung, klien akhirnya dapat memahami bahwa apa yang ia inginkan hanyalah bercerita soal masalahnya. Pada akhir sesi tersebut terdapat percakapan seperti dikutip pada contoh 2 .

\section{Contoh 2:}

Klien : Saat saya berada di kantor sebelumnya, saya tahu saya harus melepaskan masalah saya ini di 
suatu tempat. Saya merasa saya bisa datang ke kamu dan menceritakan. Saya tahu kamu akan paham. Saya tidak bisa mengatakan bahwa saya membenci diri saya, tak mungkin bisa. Jadi saya hanya berpikir untuk menumpahkan semua hal buruk itu kamu saja.

Konselor: Hal-hal yang kamu rasakan pada dirimu tapi tidak bisa kamu katakan, bisa kamu katakan pada saya.

Setelah melihat percakapan antara Rogers dan kliennya, dapat dilihat bahwa melakukan empati dan penerimaan tidaklah mudah. Setelah klien melampiaskan amarahnya pada Rogers, dan akhirnya dapat menceritakan alasan di balik hal itu, Rogers masih memberikan penerimaan dengan memperbolehkan klien untuk mengatakan hal tersebut ke Rogers. Hal ini didasari oleh adanya empati bahwa klien selama ini mempunyai banyak perasaan yang ingin diungkapkan tapi tidak dapat tersampaikan. Perasaanperasaan tersebut bersifat negatif dan karena lama tidak terungkapkan, mempengaruhi bagaimana klien memandang dirinya. Ia pun memandang dirinya buruk seperti perasaan-perasaan negatif yang tidak pernah dapat ia ungkapkan tanpa judgment. Dengan adanya empati tersebut, Rogers memberikan penerimaan pada kondisi klien. Jika klien terus mendapatkan empati dan penerimaan, ia lebih dapat juga menerima dirinya dan mengungkapkan emosi-emosinya secara lebih adaptif. Oleh karena itu, emosi negatif maupun positif yang ditujukan pada Konselor perlu disikapi dengan empati dan penerimaan oleh Konselor. Konselor perlu membantu klien untuk mengungkapkan emosi tersebut namun juga membantunya menyadari bahwa emosi tersebut sebenarnya bukanlah ditujukan pada Konselor, tapi pada dirinya sendiri atau akumulasi dari berbagai hal yang pernah dialami klien.

\section{KESIMPULAN}

Tulisan ini memaparkan berbagai contoh kondisi di mana konselor, yaitu Carl Rogers dan Natalie Rogers, mampu menerapkan konsep actualizing tendency dan formalizing tendencey ini pada berbagai kondisi konseling, yaitu (1) menanggapi pertanyaan klien, memberikan respons terhadap blocking klien, (3) merefleksikan muatan emosi terhadap cerita klien, dan merefleksikan muatan emosi klien yang ditujukan ke Konselor. Kondisi ini tentu saja dapat dihadapi oleh Konselor pada pendekatan apa pun. Menghadapi kondisi ini, tanpa adanya empati dan penerimaan, tentunya membuat kondisi konselor 
menjadi kurang nyaman, baik bagi klien maupun Konselor. Akan tetapi, memberikan empati dan penerimaan memang membutuhkan keterampilan yang relatif sulit, terutama pada kondisi keempat. Konselor benar-benar perlu menunjukkan empati dan penerimaan yang besar untuk tidak terpengaruh kondisi emosional klien, dan hal ini bukanlah suatu yang klise.

\section{DAFTAR PUSTAKA}

De Stefano, J., Mann-Feder, V., \& Gazzola, N. (2010). A qualitative study of client experiences of working with novice counsellors. Counselling and Psychoterapy Research, 10, 2, 139146.

Frankel, M., Rachlin, H., \& Yip-Bannicq, M. (2012). How nondirective therapy directs: The power of empathy in the context of unconditional positive regard. Person-Centered \& Experiential Psychotherapies, 11(3): 205-214.

Kim, S. (2010). A Story of a Healing Relationship: The Person-Centered Approach in Expressive Arts Therapy. Journal of Creativity in Mental Health, 5, 93-98.

Lewis, M.K., Rogers, C.R., \& Shlien, J.M. (2008). Time-limited client-centered psychotherapy: One case. In Tudor, K. (editor). Brief Person-Centered Therapies. Los Angeles: Sage.

PsychotherapyNet. (2012, November 9). Expressive Arts Therapy Video with Natalie Rogers Video [Video file]. Retrieved from https://www.youtube.com/watch? $\mathrm{v}=\mathrm{sd} 6$ 2Al_NsYU

Rogers, C. (1980). A way of being. Boston: Houghon-Mifflin

Rogers, N., Tudor, K., Tudor, L. E., \& Keemar, K. (2012). Person-centered expressive arts therapy: A theoretical encounter. Person-Centered \& Experiential Psychotherapies, 11(1), 31-47.

http://doi.org/10.1080/14779757.2012 .656407

Satyajati, M.W. (2016). Person-Centered Expressive Arts Therapy untuk Meningkatkan Efikasi Diri Konselor Adiksi. Tesis (tidak dipublikasikan). Yogyakarta: Universitas Gadjah Mada.

Satyajati, M.W., \& Iswari, R.D. (2015). Membebaskan Kritik Diri dengan Menggambar: Studi Kasus Terapi Seni berbasis Pendekatan Person-Centered pada Permasalahan Gangguan Panik. Prosiding Konferensi Nasional Pengkajian Seni: Arts and Beyond, halaman 459-475.

Singh, A.N., \& Strand, P.S. (2008). A Person-Centered, strength-based treatment of aggression and sexually inappropriate behavior in mental health. Clinical Case Studies, 7 (5), 397-408, doi: $10.1177 / 1534650108316935$

Ursano, R.J., Sonnenberg, M.D., \& Lazar, S.G. (2004). Concise Guide to Psychodinamic Psychotherap: principles and techniques of brief, intermittent, and long-term psychodynamic psychotherapy. Arlington: American Psychiatric Publishing. 